\title{
Article \\ A Preliminary Survey on the Planktonic Biota in a Hypersaline Pond of Messolonghi Saltworks (W. Greece)
}

\author{
George N. Hotos
}

check for updates

Citation: Hotos, G.N. A Preliminary Survey on the Planktonic Biota in a Hypersaline Pond of Messolonghi Saltworks (W. Greece). Diversity 2021, 13, 270. https://doi.org/10.3390/ d13060270

Academic Editor: Michael Wink

Received: 24 May 2021

Accepted: 12 June 2021

Published: 15 June 2021

Publisher's Note: MDPI stays neutral with regard to jurisdictional claims in published maps and institutional affiliations.

Copyright: (C) 2021 by the author. Licensee MDPI, Basel, Switzerland. This article is an open access article distributed under the terms and conditions of the Creative Commons Attribution (CC BY) license (https:/ / creativecommons.org/licenses/by/ $4.0 /)$.
Plankton Culture Laboratory, Department of Animal Production, Fisheries \& Aquaculture, University of Patras, 30200 Messolonghi, Greece; ghotos@upatras.gr

\begin{abstract}
During a survey in 2015, an impressive assemblage of organisms was found in a hypersaline pond of the Messolonghi saltworks. The salinity ranged between 50 and $180 \mathrm{ppt}$, and the organisms that were found fell into the categories of Cyanobacteria (17 species), Chlorophytes (4 species), Diatoms (23 species), Dinoflagellates (1 species), Protozoa (40 species), Rotifers (8 species), Copepods (1 species), Artemia sp., one nematode and Alternaria sp. (Fungi). Fabrea salina was the most prominent protist among all samples and salinities. This ciliate has the potential to be a live food candidate for marine fish larvae. Asteromonas gracilis proved to be a sturdy microalga, performing well in a broad spectrum of culture salinities. Most of the specimens were identified to the genus level only. Based on their morphology, as there are no relevant records in Greece, there is a possibility for some to be either new species or strikingly different strains of certain species recorded elsewhere.
\end{abstract}

Keywords: protists; cyanobacteria; rotifers; crustacea; hypersaline conditions; Messolonghi saltworks

\section{Introduction}

It is well known that saltwork waters support high algal densities due to the abundance of nutrients concentrated by evaporation [1-3]. Apart from the fact that such ecosystems are of paramount ecological value, they are also a potential source for tolerant biota that can be exploited for aquaculture [4] or other uses [5,6]. Generally, in hypersaline systems, the microbial life in the prokaryotic level (halophilic archaea and bacteria) has been extensively described, (e.g., [7,8]) emphasizing their role (in addition to viruses) as highly essential in the biogeochemical processes. The eukaryotic invertebrate biota in hypersalinity lagged considerably in terms of diversity and interaction with all elements of this environment, resulting in a poor understanding of its role in the dynamics of food webs. In most works concerning protists or crustacea, the halotolerant green alga Dunaliella spp. (e.g., $[9,10])$ occupies the bulk of studies for algae, and the anostacan Artemia (e.g., [11,12]) for planktonic invertebrates.

Considering the scarcity of adequate information on organisms other than bacteria from hypersaline environments in Greece [13], a preliminary survey in the salterns of Messolonghi (W. Greece) was made throughout the spring and summer of 2015. The aim was to identify all organisms visible by optical microscopy to the genus level in order to gain an understanding of their presence and abundance as a guide for future, detailed studies in this biotope. A further aim involved testing the potential for maintenance and culture of all possible organisms in laboratory conditions for their use as live food for aquaculture and other general use. The situation is perplexing, as the topic of cyanobacteria and protists (algae and protozoa) from hypersalinity is highly varied in the literature. As images are essential for identifying species, pictures and live videos were taken by microscopy, and material is presented here.

\section{Materials and Methods}

The water samples were taken from a particular pond of the Messolonghi saltworks, lying between the coordinates $38^{\circ} 23^{\prime} 47^{\prime \prime}$ to $38^{\circ} 23^{\prime} 31^{\prime \prime} \mathrm{N}$ and $21^{\circ} 24^{\prime} 17^{\prime \prime}$ to $21^{\circ} 24^{\prime} 33^{\prime \prime}$ E. 
Samples were taken during April-September 2015 on a monthly basis, thus following the salinity range (50-180 ppt) of the changing water conditions. The pond ( 12 ha) is located at the periphery of the saltworks complex and is connected to the Messolonghi lagoon by a narrow channel, the water of which is manageably diverted to fill the evaporation ponds of the saltworks. In contrast to the main evaporation ponds that produce salt, this pond is filled with water throughout the whole year. Although evaporation gradually increases the pond's salinity from April onwards, it never becomes dry, its water level remaining between 0.4 and $1.7 \mathrm{~m}$ at its deepest central area. The samples were only water with no benthos included. A 2 L plastic beaker was used, with only the surface of the bottom touching, in order for the water to be disturbed just enough for the top layer to be included in the sample ( $\sim .7 \mathrm{~m}$ from the shore). Salinity and temperature were recorded, and the samples were immediately transported to the laboratory where the temperature was kept at $22{ }^{\circ} \mathrm{C}$. The samples were kept in $2 \mathrm{~L}$ Erlenmeyer conical flasks, lit with ambient light of about $20 \mu \mathrm{mol} \mathrm{m}{ }^{-2} \mathrm{~s}^{-1}$, and aerated using pumped air via a pipette. There were 2 sub-samples of $50 \mathrm{~mL}$ taken and centrifuged mildly (SIGMA 3K10, Sigma Laborzentrifugen $\mathrm{GmbH}$, Osterode, Germany) at $3000 \mathrm{rpm}$ for $3 \mathrm{~min}$ after which the sediment with $2 \mathrm{~mL}$ of water was kept for microscopical examination. The decanted supernatant was free of organisms, as they were sedimented and then kept in the resuspended $2 \mathrm{~mL}$ of the vial. There were no adverse effects of the centrifugation on the motility and viability of the organisms. The procedure for the $50 \mathrm{~mL}$ sub-samples was repeated for 3 successive days in order to strengthen the detection. The $2 \mathrm{~mL}$ concentrated samples were apportioned to $0.1 \mathrm{~mL}$ sub-samples as droplets in shallow, glass, Petri dishes and examined microscopically (Leica Labovert FS inverted microscope and Leika Leitz DMRB) in order to count organisms larger than $30 \mu \mathrm{m}$. This included all protozoa, rotifers, copepods, Artemia and nematodes. After a thorough counting assessment of the live specimens, a drop of Lugol was added, and the immobilized organisms were counted once more. The other $2 \mathrm{~mL}$ sample was kept intact (without Lugol) in order to be examined microscopically for microalgae using the Leica DM-RB microscope at $400 \times$ magnification.

Additionally, from the live samples, organisms were targeted and removed by micropipette suction and placed in 6 well multi-chamber plates (SARSTEDT) with $4 \mathrm{~mL}$ of Walne's nutrient fertilized water (enriched with silica in case of diatoms) of similar salinity to that of their most abundance. This was carried out in order to test their potential for growth in culture conditions as a preliminary trial for the feasibility to be mass cultured. The culture plates were left to mature in the laboratory (at $22-23{ }^{\circ} \mathrm{C}, 12: 12 \mathrm{~h}$ light:dark, illumination at $50-60 \mu \mathrm{mol} \mathrm{m}{ }^{-2} \mathrm{~s}^{-1}$ without aeration). The plates were examined after 10 days for population increase. It was noted that during this 10-day period, due to the initial low density of organisms in each chamber, there were no adverse effects of metabolic waste on them. When the cultures were algae, the density was calculated using a FuchsRosenthal hematocytometer. If the cultures were protozoa, rotifers, copepods or Artemia, then to start, $0.2 \mathrm{~mL}$ of dense phytoplankton that was previously cultured and comprised of Asteromonas gracilis and Dunaliella was added in order to supply adequate food. These two microalgae were selected as food on the grounds that they dominated the chlorophyte microflora of the pond and presumably served as food for the above heterotrophs in their natural habitat. After 10 days, any increase in the population was recorded in a dissecting microscope (Nikon SMZ-U). The abundance of the various organisms (less than $30 \mu \mathrm{m}$ in size) in the sub-sample mixtures taken from the various salinity samples was calculated as the counted individuals of each species in a $1 \mathrm{~mm}^{2}$ area of the microscopy vision field. Counts were used for comparisons among salinities for a rough estimation of abundance. All photos presented here were taken (Jenoptik Progres Gryphax Arktur digital microscopy camera) from live specimens after immobilization in the freezer for about $1 \mathrm{~h}$ (Figures 1-7). For identification of the organisms, various studies were used as guides [14-19]. 

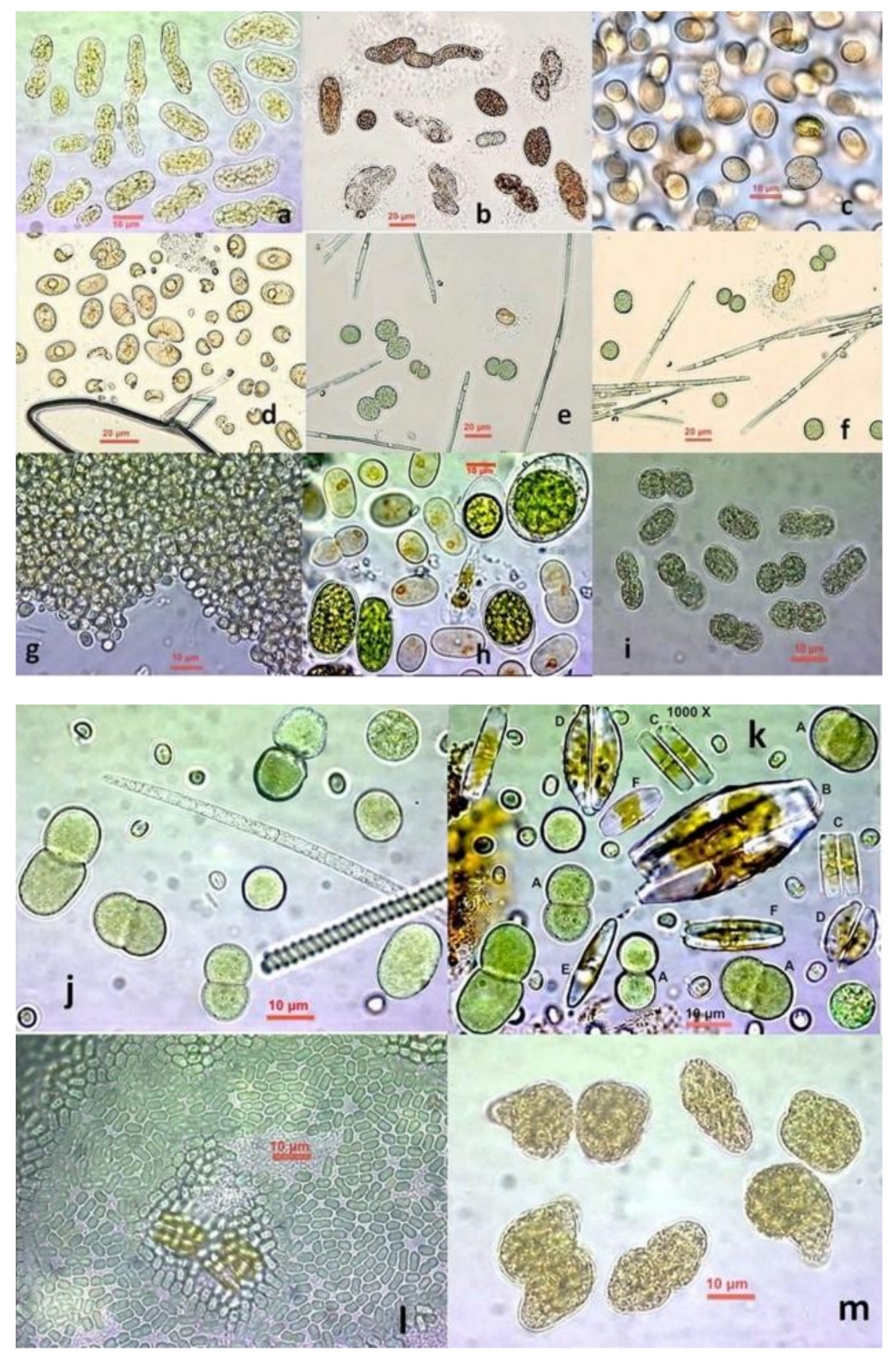

Figure 1. Cocciform Cyanobacteria from hypersalinity at Messolonghi saltworks. (a) Peculiar involuted cells of an unidentified species; (b) variously shaped cells, sole, involuted and dividing, probably of genus Synechococcus and in some of them with a mucilage layer around cells; (c) totally unknown species; (d) kidney-shaped cells of an unknown species; (e,f) various cells of genus Cyanothece in division state; (g) Microcystis sp. colony; (h) Synechococcus-like cells among normal and palmelloid cells of the chlorophyte Tetraselmis marina; (i) probably Synechococcus sp.; (j) Cyanothece sp. cells at various stages of division along with an Arthrospira sp. filament; (k) Aphanothece sp. and Cyanothece sp. cells along with pennate diatoms; (1) dense colony of small greenish cells of the Synechococcus type; (m) peculiar involuted cells of probably Synechococcus sp. 

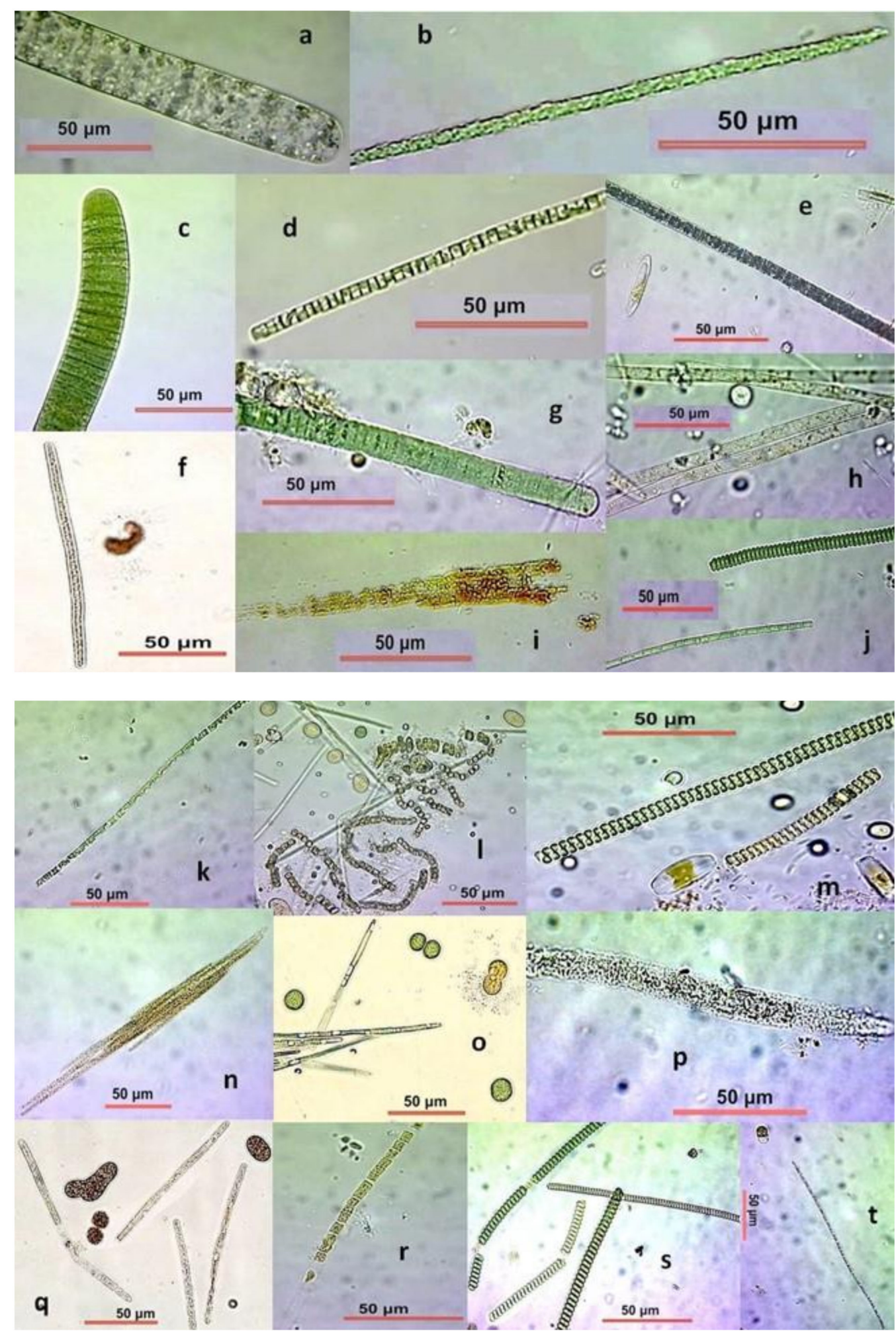

Figure 2. Filamentous Cyanobacteria from hypersalinity ponds. (a) Oscillatoria sp.; (b) unidentified trichome; (c) Oscillatoria sp.; (d) unidentified trichome; (e) Beggiatoa sp.?; (f) unidentified; (g) Lyngbya sp.; (h) Tychonema sp.; (i) Aphanizomenon sp.; (j) Pseudoanabaena sp.? and Arthrospira sp.; (k) Prochlorothrix sp.; (1) Anabaena sp.; (m) Arthrospira sp. thick and thin filaments; (n) Aphanizomenon sp.; (o) Prochlorothrix sp.?; (p) Cylindrospermopsis sp.?; (q) Beggiatoa sp. among Synechococcus; (r) Cylindrospermopsis sp.; (s) fragmented Arthrospira filaments of various thickness; (t) Cylindrospermopsis sp.? 

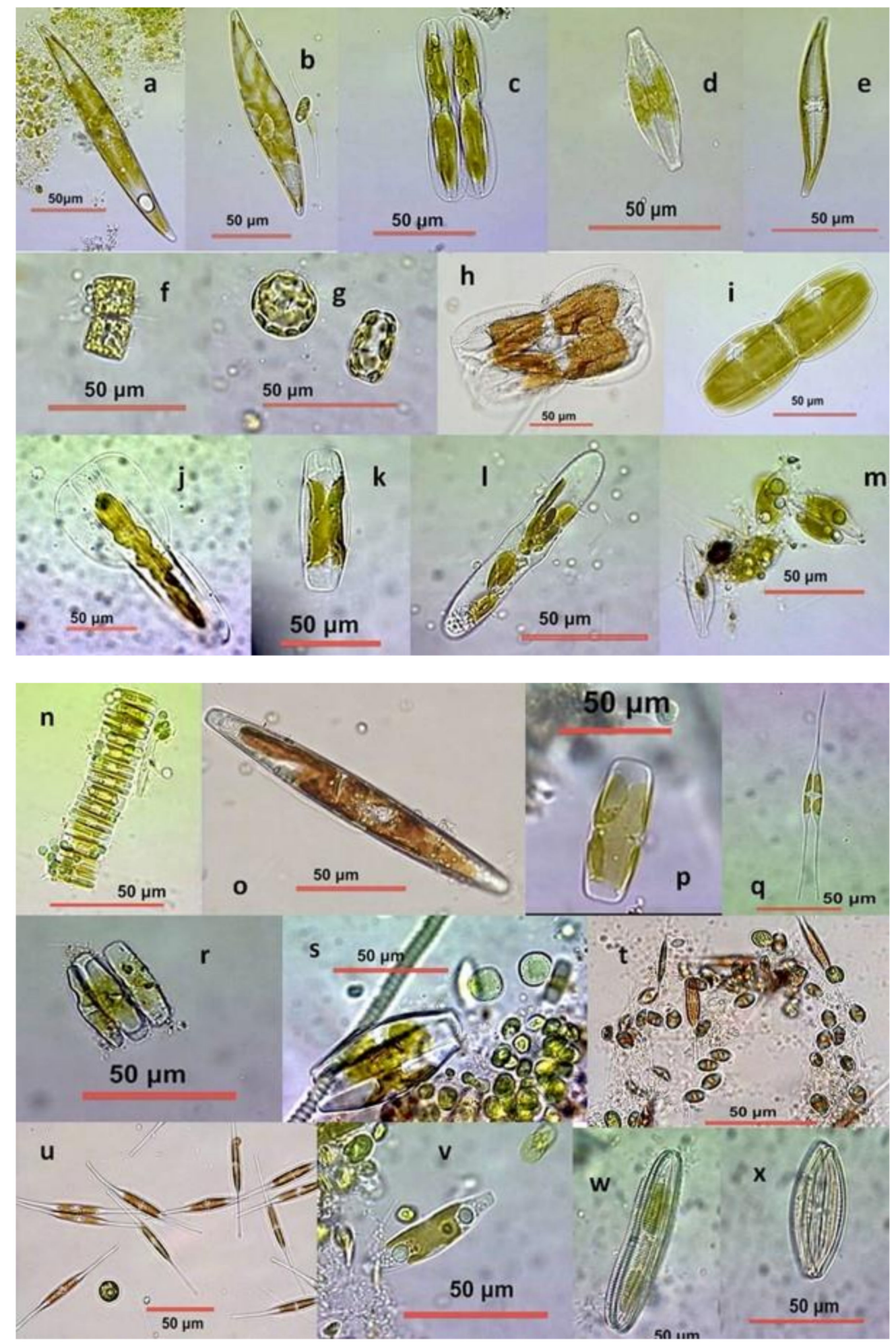

Figure 3. Diatoms from hypersalinity. (a) Pleurosigma sp., lateral view; (b) Pleurosigma sp., girdle view; (c) Entomoneis sp.; (d) Navicula sp.; (e) Gyrosigma sp.; (f) Cyclotella sp. dividing; (g) Cyclotella sp. round and elongated form; (h) Entomoneis sp.; (i) Amphiprora sp.?; (j) Gomphonema sp.?; (k) unidentified cymbelloid species; (1) Pinnularia sp.?; (m) Cymbella sp.; (n) Eunotia sp.?; (o) Nitzschia sp.; (p) unidentified diatom; (q) Nitzschia dividing; (r) Eunotia sp.?; (s) Cymbella sp.; (t) Cocconeis sp.; (u) Cylindrotheca sp.; (v) Craticula sp.; (w) Epithemia sp.?; (x) Diatoma sp.(same scale bar as that in w). 


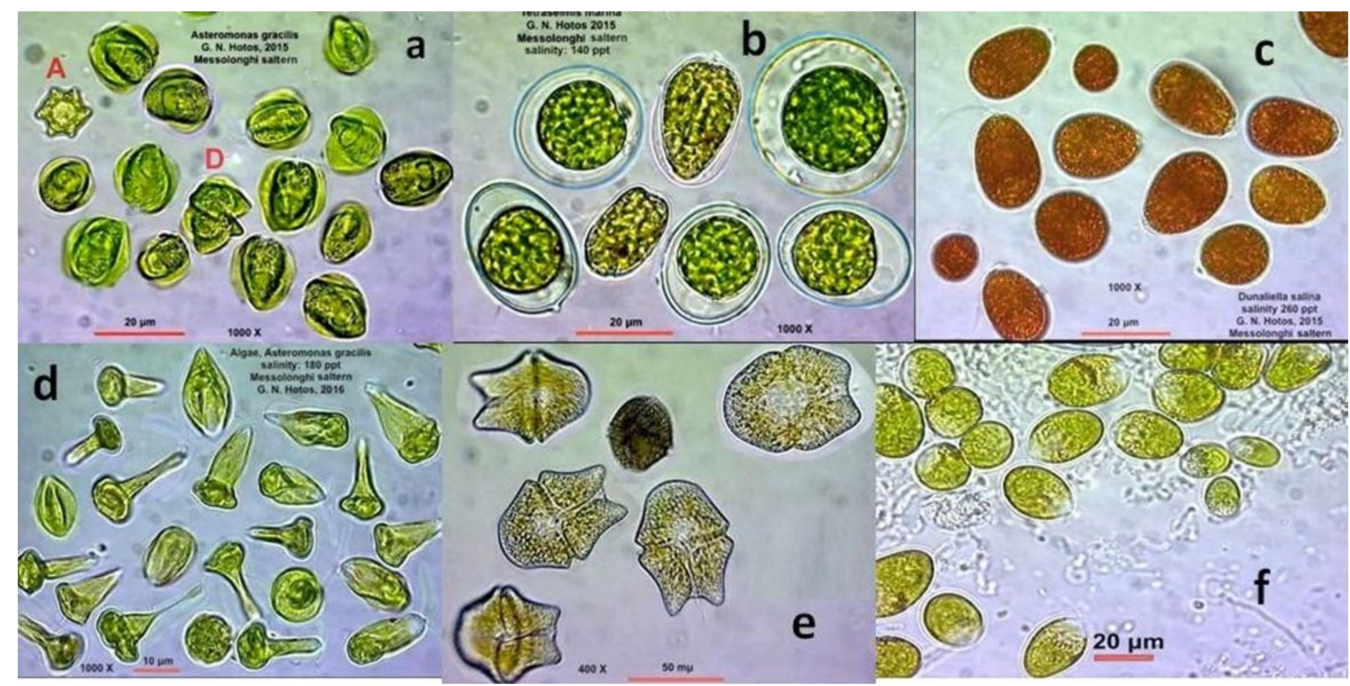

Figure 4. The dominant chlorophytes and dinophytes in hypersalinity. (a) Asteromonas gracilis; (b) Tetraselmis marina, normal and palmelloid cells; (c) Dunaliella sp., reddish cells full of carotenoids at 180 ppt salinity; (d) Asteromonas gracilis in peculiar cell shapes; (e) the dinoflagellate Gymnodinium sp.; (f) Dunaliella sp., green cells at 100 ppt salinity.
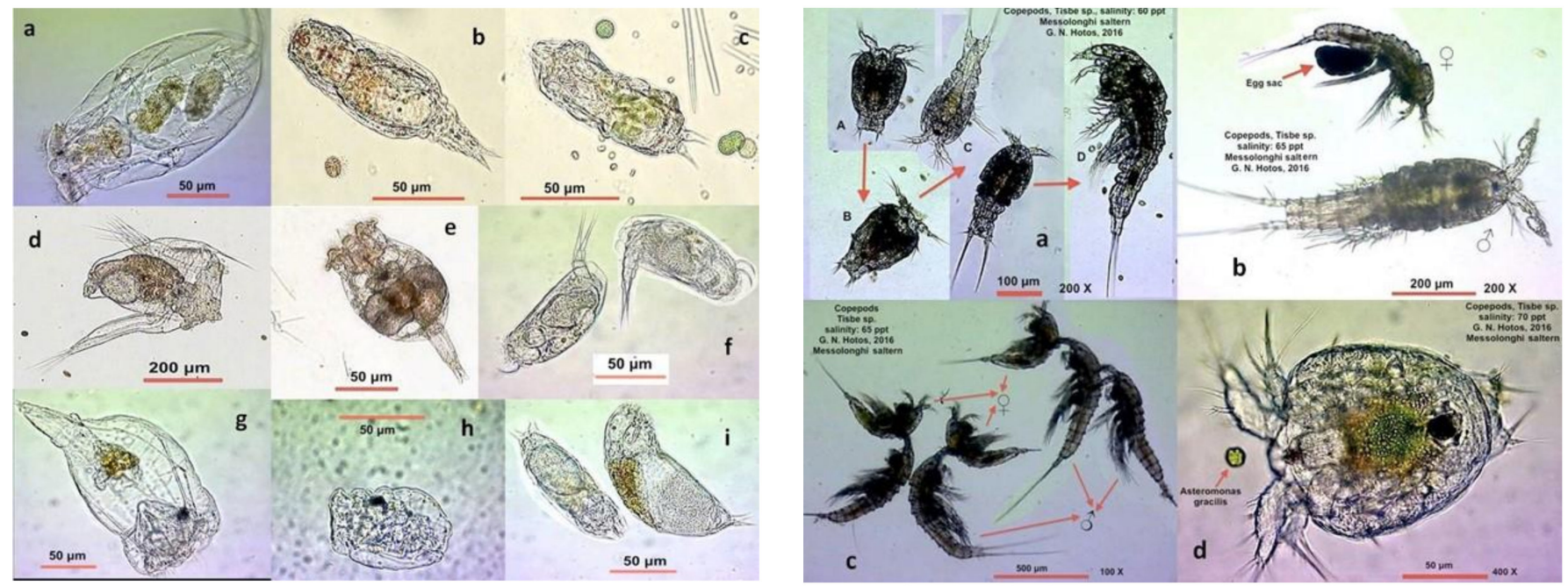

Figure 5. Metazoa from hypersalinity. Left plate: rotifers, (a) Testudinella sp.; (b) Pleurotrocha sp.; (c) Lindia sp.; (d) Hexarthra sp.; (e) Brachionus plicatilis; (f) Colurella sp.; (g) Epiphanes sp.; (h) unidentified marine rotifer; (i) Encentrum sp. Right plate: copepod Tisbe sp., (a) various ontogenic stages, A: early nauplius, B: late nauplius, C: copepodites, D: adult; (b) male and female individuals; (c) copulation captured photo; (d) Tisbe nauplius fed Asteromonas cells. 


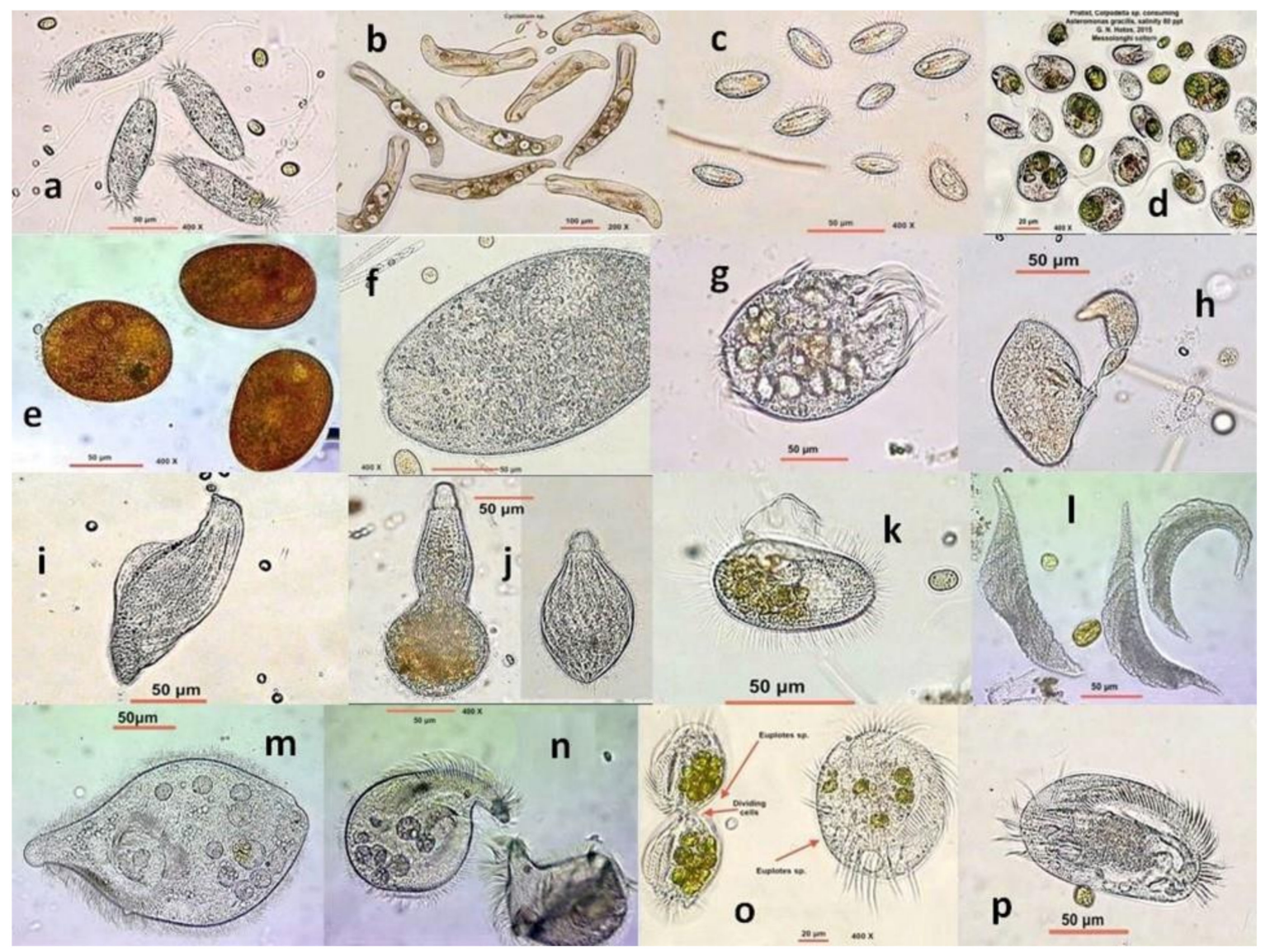

Figure 6. Representative ciliate Protozoa from a hypersaline pond of Messolonghi saltworks. (a) Litonotus sp.?; (b) Condylostoma sp.; (c) Cyclidium sp.; (d) Colpodella sp.; (e) Frontonia sp.; (f) Climacostomum sp.; (g) Uronychia sp.; (h) Holophrya sp. in budding reproduction; (i) Loxodes sp.; (j) Phialina sp.; (k) Pleuronema sp.; (1) Amphileptus sp.; (m) Fabrea salina at 90 ppt; (n) Fabrea salina at 170 ppt; (o) Euplotes sp. in division, full of Asteromonas cells (left); (p) Euplotes sp.
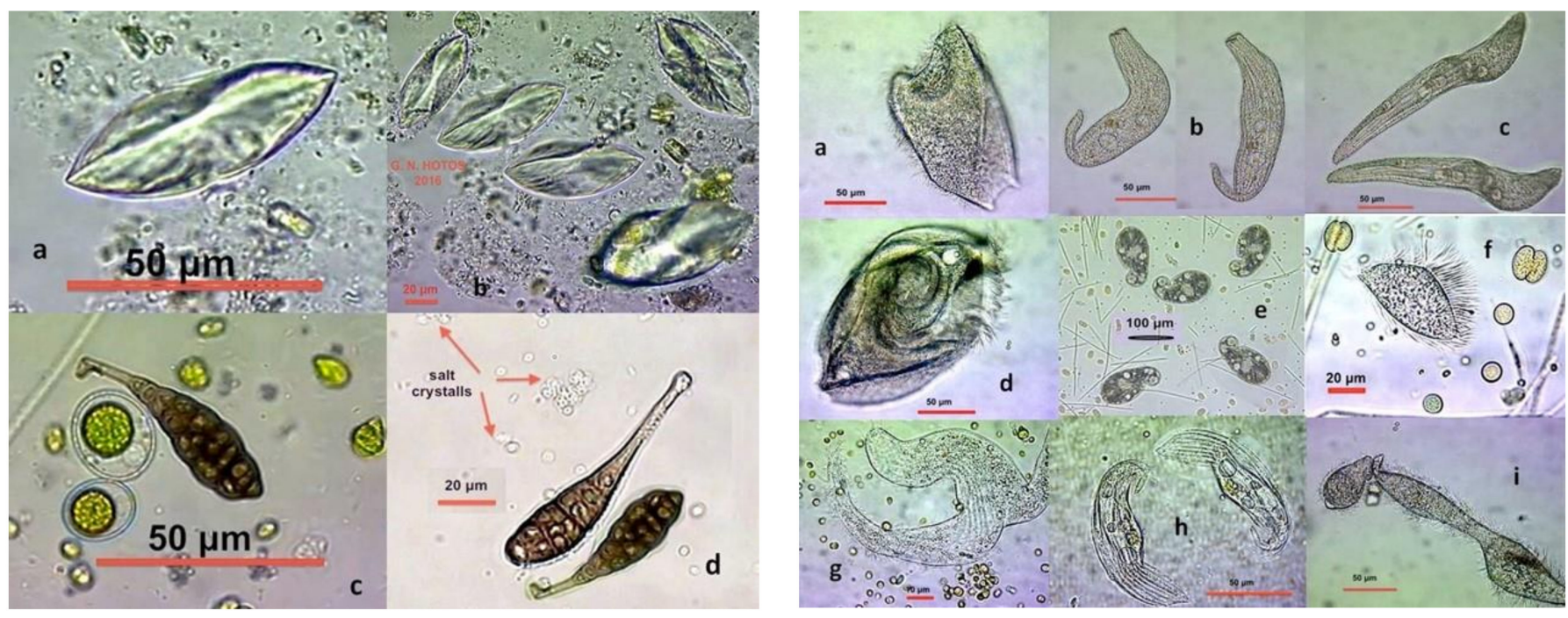

Figure 7. Unidentified organisms and fungi spores from the hypersalinity ponds of Messolonghi saltwork. Left plate: (a,b), unidentified microbes among peculiar salt crystals at 175 ppt, (c,d), Alternaria sp. (fungi) spores at 90 ppt. Right plate: (a-i), ciliates not resembling anything known from Protozoan atlases. 


\section{Results and Discussion}

The organisms found (Table 1) can be categorized as Cyanobacteria, Protozoa, eucaryotic microalgae, rotifers, copepods, Artemia, a nematode and fungi. The salinity range clearly demarcated the presence of some organisms from others. In particular, at salinities over 160 ppt, only Artemia sp., Dunaliella sp., Asteromonas gracilis, Fabrea salina and some cocciform cyanobacteria were detected and able to stay alive and grow at similar (with their occurrence) salinities in laboratory conditions. An unusual finding was that while some genera of cyanobacteria were detected in mass at elevated salinities, their subsequent culture at similar salinities in the laboratory yielded poor results. It seems that a combination of elusive parameters in their specific natural habitat fulfills their needs. In the salinity range of 110-160 ppt, many more organisms (included those previously mentioned) were recorded with representatives from all categories except rotifers and copepods. At salinities of 60-110 ppt, cyanobacteria, rotifers and protozoa were more abundant than in higher salinities. Fabrea salina, a well-documented ciliate in saline water bodies (>35 ppt) all over the world (e.g., $[20,21])$, dominated in all salinities. It was easily mass cultured at almost every salinity in the range of 35-150 ppt, thus being a candidate live food for larval marine fish. At salinities higher than $160 \mathrm{ppt}$, F. salina encysts can remain viable for a long time [22], reviving again after lowering the salinity below 50 ppt (unpublished data). F. salina plays a crucial role within the food web in hypersaline waters through being a consumer of Dunaliella sp. [13,23] and in the quality of its salt production [24]. However, the statement in [13] that F. salina produces slime must be rejected, as this is rather the result of mucus excretion of several cocciform cyanobacteria (personal observations, unpublished) or glycerol overproduction of Dunaliella, a genus notorious for this process in high salinities [25]. The copepod Tisbe sp. also exhibited remarkable viability in a wide range of salinities (35-90 ppt) and was easily cultured with a high reproduction rate, feeding heavily on a wide spectrum of microalgae. Its culture can remain viable even in water with a heavy organic load without added food; therefore, it is considered to be a hardy species for larval aquaculture. The green Chlorophytes (A. gracilis, Tetraselmis marina and Dunaliella sp.) were easily mass cultured, showing better growth at salinities over 100 ppt. T. marina was the most sensitive of the three, as for unknown reasons, its cells often lose all four flagella and are transformed to palmelloid cells [26]. Nevertheless, these three halotolerant microalgae proved to be an excellent food source for the rotifer Brachionus plicatilis, copepods, Artemia and the ciliate F. salina. Considering the variety of information in the literature on the presence of all the above categories of organisms in hypersalinity (e.g., $[20,21,27])$, a wide field awaits to be studied in detail. In particular, the spectrum of the actual number of species of cyanobacteria and protists may be much broader than presented here. Endemicity may also be much more intense than conservatively thought. The species in Greece may be different from saltworks in adjacent countries, noting that there are few natural hypersaline lakes in Europe. This remains true, especially when more remote areas on Earth are considered. Saltworks are not naturally formed and evolved biotopes but rather reflect the conditions in which the extreme edge of acclimation and adaptation of the marine organisms that are constantly transported from the sea to the saltpans can be observed. Consequently, the endemicity theory refers to the sea habitat. In that sense, Foissner's (2008) [28] moderate endemicity distribution model in protists as opposed to the ubiquity distribution model seems to explain the findings of the present study, even in this case whereby recognition was based on morphology and confined to the genus and not to the species level of the encountered organisms. It seems that apart from protists, this hypothesis also applies to hypersaline cyanobacteria; thus, an entire unexplored eco-habitat awaits a multidisciplinary approach. The present study should be considered as a preliminary attempt to outline the wealth of micro-biota in a specific, local hypersaline environment. With the aim of igniting interest for further elaboration in future studies, the organisms presented in Figures 1-7 are representatives of the whole collection. 
Table 1. The organisms recorded in hypersalinity at Messolonghi saltworks identified to the genus level. "+" stands for the least presence, " ++++" for maximum and "- " for absence in relation to the counts sum of each particular organism across salinities (absolute abundance) and in combination with a rather rough estimation of their relative abundance among all other organisms in each particular sample examined. Concerning their response to the culture trials, notations in the column "Culture Response" mean: " 0 " = no change or decrease in the initial number of organisms, " $1 \times-2 \times$ " $=$ increase of $1-2$ times in the initial number of organisms, " $2 \times-3 \times$ ", = increase of $2-3$ times, " $3 \times-4 \times$ " $=$ increase of 3 -4 times, " $>4 \times$ " $=$ increase of over 4 times. Detailed records in the Supplementary Material of Table S1.

\begin{tabular}{|c|c|c|c|c|c|c|}
\hline Salinity Range (ppt) & $50-80$ & $81-110$ & $111-130$ & $131-160$ & $>160$ & Culture Response \\
\hline \multicolumn{7}{|l|}{ CYANOBACTERIA } \\
\hline Synechococcus & +++ & ++++ & ++++ & + & + & $1 \times-2 \times$ \\
\hline Aphanothece & ++ & +++ & ++++ & + & - & 0 \\
\hline Microcystis & ++++ & +++ & ++ & - & - & 0 \\
\hline Cyanothece & + & ++ & ++++ & +++ & + & $3 \times-4 \times$ \\
\hline Oscillatoria & ++++ & +++ & ++ & - & - & $1 \times-2 \times$ \\
\hline Lyngbya & ++++ & ++ & + & - & - & 0 \\
\hline Aphanizomenon & +++ & ++++ & ++ & - & - & \\
\hline Cylindrospermopsis & ++ & +++ & + & + & - & \\
\hline Anabaena & +++ & + & - & - & - & $1 \times-2 \times$ \\
\hline Arthrospira & +++ & ++++ & ++++ & ++ & - & $1 \times-2 \times$ \\
\hline Beggiatoa & ++ & + & - & - & - & \\
\hline Scytonema & ++ & + & - & - & - & \\
\hline Prochlorothrix & + & - & - & - & - & \\
\hline Microcoleus & + & - & - & - & - & \\
\hline Tychonema & + & - & - & - & - & \\
\hline Pseudoanabaena & ++ & + & - & - & - & \\
\hline Phormidium & ++++ & + & - & - & - & $>4 \times$ \\
\hline \multicolumn{7}{|l|}{ PROTOZOA } \\
\hline Euplotes & ++++ & ++++ & ++ & + & - & $>4 \times$ \\
\hline Uronychia & ++++ & + & - & - & - & $1 \times-2 \times$ \\
\hline Diophrys & ++++ & + & - & - & - & \\
\hline Frontonia & ++++ & ++ & + & - & - & 0 \\
\hline Dysteria & + & & & & & \\
\hline Aspidisca & ++++ & ++++ & ++ & - & - & \\
\hline Paramecium & ++++ & ++ & - & - & - & $1 \times-2 \times$ \\
\hline Euglena & ++ & - & - & - & - & $1 \times-2 \times$ \\
\hline Paraurostyla & +++ & ++ & + & - & - & \\
\hline Colpoda & ++++ & +++ & ++ & - & - & \\
\hline Coleps & ++ & - & - & - & - & $1 \times-2 \times$ \\
\hline Amphileptus & +++ & + & + & - & - & \\
\hline Condylostoma & ++++ & +++ & ++ & + & - & $2 \times-3 \times$ \\
\hline Amoeba & ++++ & ++++ & ++ & + & - & $2 \times-3 \times$ \\
\hline Holophrya & ++++ & ++ & + & + & - & \\
\hline
\end{tabular}


Table 1. Cont.

\begin{tabular}{|c|c|c|c|c|c|c|}
\hline Salinity Range (ppt) & $50-80$ & 81-110 & 111-130 & $131-160$ & $>160$ & Culture Response \\
\hline Halteria & ++ & + & - & - & - & 0 \\
\hline Pleuronema & ++++ & ++ & ++ & + & - & $1 \times-2 \times$ \\
\hline Cyclidium & ++++ & ++++ & +++ & ++ & - & $2 \times-3 \times$ \\
\hline Loxodes & ++ & ++ & + & - & - & \\
\hline Litonotus & ++ & + & + & - & - & $1 \times-2 \times$ \\
\hline Chaetospira & +++ & + & + & + & - & \\
\hline Stichotria & +++ & + & + & - & - & \\
\hline Bursaridium & ++ & +++ & - & - & - & \\
\hline Climacostomum & ++++ & +++ & ++ & + & - & \\
\hline Blepharisma & ++++ & +++ & ++ & - & - & \\
\hline Holosticha & ++++ & ++ & + & - & - & \\
\hline Vorticella & ++++ & +++ & ++ & + & - & $2 \times-3 \times$ \\
\hline Remanella & ++++ & ++ & + & + & - & \\
\hline Lembandion & ++ & - & - & - & - & \\
\hline Strobidium & ++ & + & - & - & - & \\
\hline Uronema & ++++ & ++++ & ++ & + & - & \\
\hline Bursaria & ++ & - & - & - & - & \\
\hline Tracheloraphis & ++ & - & - & - & - & \\
\hline Lacrymaria & + & - & - & - & - & \\
\hline Hemiophrys & ++ & + & - & - & - & \\
\hline Fabrea salina & ++++ & ++++ & ++++ & ++++ & ++ & $>4 \times$ \\
\hline Dileptus & ++++ & + & - & - & - & \\
\hline Colpodella & ++++ & +++ & ++ & - & - & $2 \times-3 \times$ \\
\hline Phialina & +++ & ++ & + & - & - & \\
\hline Choanoflagellates & ++ & + & - & - & - & \\
\hline \multicolumn{7}{|l|}{$\begin{array}{l}\text { MICROALGAE } \\
\text { (Chlorophytes) }\end{array}$} \\
\hline Asteromonas gracilis & ++ & ++++ & ++++ & ++++ & ++++ & $>4 \times$ \\
\hline Dunaliella & ++++ & ++++ & ++++ & ++++ & ++++ & $>4 \times$ \\
\hline Tetraselmis marina & ++ & ++++ & +++ & + & - & $2 \times-3 \times$ \\
\hline Hymenomonas & ++++ & ++ & - & - & - & 0 \\
\hline \multicolumn{7}{|l|}{$\begin{array}{l}\text { MICROALGAE } \\
\text { (Diatoms) }\end{array}$} \\
\hline Cymbella & ++++ & +++ & +++ & + & - & $1 \times-2 \times$ \\
\hline Caloneis & ++ & + & - & - & - & \\
\hline Cyclotella & ++++ & + & - & - & - & $3 \times-4 \times$ \\
\hline Craticula & ++ & + & - & - & - & \\
\hline Navicula & ++++ & ++++ & +++ & ++ & - & \\
\hline Nitzschia & ++++ & ++++ & ++++ & +++ & - & $>4 \times$ \\
\hline Pleurosigma & ++++ & +++ & ++ & - & - & \\
\hline Entomoneis & +++ & + & - & - & - & \\
\hline
\end{tabular}


Table 1. Cont.

\begin{tabular}{|c|c|c|c|c|c|c|}
\hline Salinity Range (ppt) & $50-80$ & 81-110 & 111-130 & $131-160$ & $>160$ & Culture Response \\
\hline Encyonema & ++ & + & - & - & - & \\
\hline Ulnaria & + & - & - & - & - & \\
\hline Pinnularia & ++ & + & - & - & - & \\
\hline Surinella & + & + & - & - & - & \\
\hline Neidium & ++ & - & - & - & - & \\
\hline Synendra & ++++ & ++ & + & + & - & \\
\hline Stauroneis & + & + & - & - & - & \\
\hline Gyrosigma & ++++ & ++ & + & - & - & $2 \times-3 \times$ \\
\hline Amphiprora & + & - & - & - & - & \\
\hline Eunotia & ++ & - & - & - & - & \\
\hline Epithemia & + & - & - & - & - & \\
\hline Diatoma & + & - & - & - & - & \\
\hline Cymatopleura & ++ & - & - & - & - & \\
\hline Cocconeis & ++++ & + & + & - & - & $2 \times-3 \times$ \\
\hline Cylindrotheca & ++ & ++ & + & + & - & $1 \times-2 \times$ \\
\hline \multicolumn{7}{|l|}{ DINOFLAGELLATES } \\
\hline Gymnodinium & ++++ & ++ & - & - & - & \\
\hline \multicolumn{7}{|l|}{ ROTIFERS } \\
\hline Hexarthra & ++ & - & - & - & - & 0 \\
\hline Pleurotrocha & ++++ & + & - & - & - & \\
\hline Epiphanes & ++ & - & - & - & - & 0 \\
\hline Encentrum & +++ & - & - & - & - & \\
\hline Lindia & ++++ & +++ & - & - & - & 0 \\
\hline Colurella & +++ & ++ & - & - & - & \\
\hline Testudinella & ++ & + & - & - & - & $1 \times-2 \times$ \\
\hline Brachionus plicatilis & ++ & - & - & - & - & $>4 \times$ \\
\hline \multicolumn{7}{|l|}{ COPEPODS } \\
\hline Tisbe & ++++ & +++ & - & - & - & $>4 \times$ \\
\hline \multicolumn{7}{|l|}{ ANOSTRACA } \\
\hline Artemia & ++++ & ++++ & ++++ & ++++ & ++++ & $>4 \times$ \\
\hline \multicolumn{7}{|l|}{ NEMATODE } \\
\hline Mesacanthoides & ++++ & ++++ & + & + & - & $>4 \times$ \\
\hline \multicolumn{7}{|l|}{ FUNGI } \\
\hline Alternaria & + & + & - & - & - & \\
\hline
\end{tabular}

Supplementary Materials: The following are available online at https: / / www.mdpi.com/article/ $10.3390 / d 13060270 / s 1$, Table S1: Records of organisms found in the monthly samples at various salinities and of their response in the culture trials.

Funding: This research received no external funding.

Institutional Review Board Statement: Not applicable.

Informed Consent Statement: Not applicable.

Data Availability Statement: Not applicable. 
Conflicts of Interest: The author declare no conflict of interest.

\section{References}

1. Javor, B.J. Planktonic standing crop and nutrients in a saltern ecosystem 1. Limnol. Oceanogr. 1983, 28, 153-159. [CrossRef]

2. Wen, Z.; Zhi-Hui, H. Biological and ecological features of inland saline waters in North Hebei, China. Int. J. Salt Lake Res. 1999, 8, 267-285. [CrossRef]

3. Davis, S.J. Biological and physical management information for commercial solar saltworks. In Proceedings of the 1st Intern Conf. Ecological Importance of Solar Saltworks (CEISSA 06), Santorini, Greece, 20-22 October 2006 ; pp. 5-14.

4. Borowitzka, M.A. Microalgae for aquaculture: Opportunities and constraints. J. Appl. Phycol. 1997, 9, 393-401. [CrossRef]

5. DasSarma, S.; Arora, P. Halophiles. In Encyclopedia of Life Sciences; Nature Publ. Group: London, UK, 2002 ; Volume 8, pp. 458-466.

6. Oren, A. Diversity of halophilic microorganisms: Environments, phylogeny, physiology, and applications. J. Ind. Microbiol. Biotechnol. 2002, 28, 56-63. [CrossRef] [PubMed]

7. Harris, J.; Caporaso, J.G.; Walker, J.J.; Spear, J.; Gold, N.J.; Robertson, C.; Hugenholtz, P.; Goodrich, J.; McDonald, D.; Knights, D.; et al. Phylogenetic stratigraphy in the Guerrero Negro hypersaline microbial mat. ISME J. 2012, 7, 50-60. [CrossRef] [PubMed]

8. Podell, S.; Ugalde, J.A.; Narasingarao, P.; Banfield, J.F.; Heidelberg, K.; Allen, E.E. Assembly-Driven Community Genomics of a Hypersaline Microbial Ecosystem. PLoS ONE 2013, 8, e61692. [CrossRef] [PubMed]

9. Oren, A. A hundred years of Dunaliella research: 1905-2005. Saline Syst. 2005, 1, 2. [CrossRef] [PubMed]

10. Ramos, A.A.; Polle, J.; Tran, D.; Cushman, J.C.; Jin, E.-S.; Varela, J.C. The unicellular green alga Dunaliella salina Teod. as a model for abiotic stress tolerance: Genetic advances and future perspectives. Algae 2011, 26, 3-20. [CrossRef]

11. Camara, M.R. Dispersal of Artemia franciscana Kellogg (Crustacea, Anostraca) Populations in the Coastal Saltworks of Rio Grande do Norte, Northeastern Brazil. Hydrobiologia 2001, 466, 145-148.

12. Saygi, Y. Characterization of the parthenogenic Artemia populations from Camalti (Izmir, Turkey) and Kalloni (Lesvos, Greece). Survival, growth, maturation, biometrics, fatty acid profiles and hatching characteristics. Hydrobiologia 2004, 52, 227-239. [CrossRef]

13. Dolapsakis, P.N.; Tafas, T.; Abatzopoulos, J.T.; Ziller, S.; Economou-Amilli, A. Abundance and growth response of micro-algae at Megalon Embolon solar saltworks in northern Greece: An aquaculture prospect. J. Appl. Phycol. 2005, 17, 39-49. [CrossRef]

14. Sournia, A. Atlas du Phytoplankton Marin. Cyanophycées, Dictyochophycées, Dinophycées, Raphidophycées; CNRS: Paris, France, 1986; p. 219.

15. Ricard, M. Atlas du Phytoplankton Marin. Diatomophycées; CNRS: Paris, France, $1987 ;$ p. 297.

16. Foissner, W.; Berger, H. A user-friendly guide to the ciliates (Protozoa, Ciliophora) commonly used by hydrobiologists as bioindicators in rivers, lakes, and waste waters, with notes on their ecology. Freshw. Biol. 1996, 35, 375-482. [CrossRef]

17. Tomas, C.R. Identifying marine Diatoms and Dinoflagellates; Academic Press: San Diego, CA, USA, 1996; 565p.

18. Lee, J.; Leedale, G.; Bradbury, P. An Illustrated Guide to the Protozoa, Volumes I E II; Society of the Protozoologists: Law-Rence, KS, USA, 2000; pp. 1-1432.

19. Fontaneto, D.; De Smet, H.W.; Melone, G. Identification key to the genera of marine rotifers worldwide. In Meiofauna Marina; Verlag, Dr. Friedrich Pfeil: München, Germany, 2008; Volume 16, pp. 75-99.

20. Basuri, C.K.; Pazhaniyappan, E.; Munnooru, K.; Chandrasekaran, M.; Vinjamuri, R.R.; Karri, R.; Mallavarapu, R.V. Composition and distribution of planktonic ciliates with indications to water quality in a shallow hypersaline lagoon (Pulicat Lake, India). Environ. Sci. Pollut. Res. 2020, 27, 18303-18316. [CrossRef] [PubMed]

21. Shadrin, N.V.; Anufriieva, E.V. Structure and Trophic Relations in Hypersaline Environments. Biol. Bull. Rev. 2020, 10, 48-56. [CrossRef]

22. Esteban, F.G.; Finlay, J.B. Marine ciliates (Protozoa) in central Spain. Ophelia 2004, 58, 13-22. [CrossRef]

23. Hotos, G. Feeding with various microalgae the salt "loving" ciliate Fabrea salina in normal salinity 35 ppt. J. Sci. Food Agric. 2019 , 3, 150-152. [CrossRef]

24. Korovesis, A.K.; Hotos, G.; Zalidis, G. The role of the ciliate protozoan Fabrea salina in solar salt production. In Proceedings of the 10th World Salt Symposium, Park City, UT, USA, 19-21 June 2018.

25. Avron, M.; Ben-Amotz, A. (Eds.) Dunaliella: Physiology, Biochemistry, and Biotechnology; CRC Press: Boca Raton, FL, USA, 1992; 256 p.

26. Hotos, G.N. A Short Review on the Halotolerant Green Microalga Asteromonas gracilis Artari with Emphasis on Its Uses. Asian J. Fish. Aquat. Res. 2019, 4, 1-8. [CrossRef]

27. Anufriieva, E.; Shadrin, N. The long-term changes in plankton composition: Is Bay Sivash transforming back into one of the world's largest habitats of Artemia sp. (Crustacea, Anostraca)? Aquac. Res. 2020, 51, 341-350. [CrossRef]

28. Foissner, W. Protist diversity and distribution: Some basic considerations. Biodivers. Conserv. 2007, 17, 235-242. [CrossRef] 